\title{
Curbing the Challenges of Multi Party System in Nigeria: The Need for Independent Candidature
}

\author{
Oluwayemi Oluwadunsin Ogunkorode \\ LL.B (Hons) Jos B.L LL.M(Ibadan) Lecturer, Department of Public Law, Faculty of Law, Ekiti State University, \\ Ado-Ekiti
}

\begin{abstract}
Multi-party system and independent candidature are no doubt dividend of democracy. Nigeria operates a multiparty system, which allows the people to decide or elect their leader through competitive elections from the numerous registered political parties. The registered political parties present their candidates through a primary election conducted within the political parties. Once the electorate votes these candidates into office, they are often more committed to their political parties than the electorates who voted them into power. Despite the avenue for multiplicity of political parties in Nigeria, the economic, social, welfare and political situation of the country has remained the same with no sign of improvement. On the other hand, independent candidature is alien to Nigerian democratic system, as it is not provided for in the Constitution and the Electoral Act. It allows an individual to contest for election without being a member of a political party. This study identified the challenges of multi-party system and the need for independent candidature in Nigeria. The relevant primary and secondary sources such as statutes, textbooks, articles, internet materials, reports etc were relied upon in this work. This study however concluded that in order to curb the excesses of political parties, independent candidature should be enacted into Nigerian law so as to give individuals who are independently minded the opportunity to contest in an election without belonging to any political party.
\end{abstract}

Keywords: Multi-party system, Political parties, Independent candidature, Nigeria, Democracy

DOI: $10.7176 / J L P G / 84-03$

Publication date: April $30^{\text {th }} 2019$

\section{Introduction}

Democratic practices and values are important for the growth and development of any democratic state. One of the dividends of democracy is the right to participate in an election, join the political party of one's choice and to elect officials into elective positions. Political parties present electorate with a choice of candidate and also help to decide the candidate that would govern the country for a fixed number of years. ${ }^{1}$ The challenges of the political parties in Nigeria started at the inception of the first political party (Nigerian National Democratic Party) in Nigeria. Despite the fact that Nigerian National Democratic Party was the only party when it was created, its political representation, activities and participation were restricted. ${ }^{2}$ Since Nigeria's recognition of the democratic process, political parties have grown to a large number and it has increased the rate of political participation in Nigeria. ${ }^{3}$ Despite the increase in the political parties in Nigeria, the principles and tenets of democracy has been brought to the barest minimum through victimisation, riot, desperation for political power, corruption, and absence of political ideology, thereby making politics a dangerous affair, which endangers the lives of the citizens. ${ }^{4}$ The increase in political parties (multiplicity of political parties) in Nigeria gives electorates ample opportunities to choose from a number of political parties that represents their ideology and interest.

Nigeria operates a multi-party system and there is no limit to the numbers of political parties that can be registered and participate in an election. One important attribute of a multi-party system, is the formation of coalition government by two or more political parties. On the other hand, unlike other countries which make legislative provision for independent candidate to participate and contest in an election. Political parties are the stakeholders in the conduct of an election in Nigeria. From the first republic to the second republic in Nigeria, several political parties have been registered and have also participated in election. Through political parties, individuals are able to pursue their political goals. Despite the multiplicity of political parties in Nigeria, there is hardly any political party that is not bedeviled with series of challenges and conflict ranging from intra party disputes, lack of internal democracy, lack of political ideology to godfatherism etc. Although multi-party system is a democratic process, it has become a threat to national unity and the democracy of a nation. Multi-party system

\footnotetext{
${ }^{1}$ A. Jinadu, Inter-party Dialogue in Nigeria: Examining the Past, Present \& Future. (Inaugural DGD Political parties dialogue series held in Abuja, 2011)

${ }^{2}$ M. Omilusi, 'Party Politics and Democratic Governance in Nigeria: Historical Perspective' (2016)(4)(4) International Journal of Multidisciplinary Academic Research

${ }^{3}$ K. K. Aaron, Multi-party System and the Crisis of Democratic Consolidation in Nigeria. (22 $2^{\text {nd }}$ world Congress of the International Political Political Science Association(IPSA) Spain, July 2012)

${ }^{4}$ P. Oyadiran and S. T. Olorungbemi, 'Party Conflicts and democratic Consolidation in Nigeria (1999-2007)' (2016)(4)(2) Global Journal of Political science and Administration
} 
gives room for fraudulent practices, election rigging, and violence and there is often confusion as to the choice of candidates and political parties. ${ }^{1}$ In a multi-party system, decision-making is often slow and it breeds ineffective, weak and localized character due to the fact that the political parties are formed based on religion and ethnicity. ${ }^{2}$ They are bedeviled with selfish goals and often identify with the interest of class, social group and ethnic groups, and the ruse to win the support of a group and make the group precursor for the fight of the undue ambition of the political elites other than independent candidature. Independent candidature does not require any form of political participation, control and it is not affected by intra/inter party conflict, rivalry, political violence etc. This study examines brief history of political parties in Nigeria, multi-party system in Nigeria, challenges of multi- party system, necessity for independent candidature and the effort of the Nigerian legislature towards the enactment of independent candidature in Nigeria.

\section{Brief history of political parties in Nigeria}

Political Party is an association of politically minded people. It is an organisation that preoccupies itself with canvassing for votes in support of candidates for election into various executive and legislative offices as designated in the Constitution. ${ }^{3}$ It is mainly interested in winning election and controlling government. ${ }^{4}$ According to Somer, a political party is an organisation that acts as a central link between the masses and the elites, it seeks political office through electoral participation. ${ }^{5}$ They are used as tools by ethnic, regional, special interest and religious groups to promote their interest to the detriment of the electorates. ${ }^{6}$ Lemay defines political parties as group of politically active persons outside a government who organise to capture by nominating and electing officials who control the operations of government and determine its policies. ${ }^{7}$ They check the excesses of government policies and programmes by serving as opposition to a ruling party. ${ }^{8}$ The history of political parties' participation in Nigeria has generated many animosity which has threatened the corporate existence and the national unity of the nation. ${ }^{9}$ The aim of political parties is to achieve electoral and political gain. It is often the belief that since Nigeria is a democratic nation, political parties in Nigeria are expected to be democratic in nature, organisation, behaviour and practice. ${ }^{10}$ Most political parties lack internal democracy and are not operating within the norms of democratic principles, which poses a lot of threats to national unity, development and democracy. ${ }^{11}$ The political mentality of winning election at all cost in Nigeria often exposes political parties to unhealthy rivalry, violence and assassination of candidates of opposition parties. While condemning the activities of political parties, Momoh stated that there is no more political education, consistent and regular grass root meeting until when election is to take place. The period of election is the only active period for political parties in Nigeria. The history of political parties in Nigeria can be traced to the Township Ordinance of 1919, which gave elective representation to the Lagos Town Council and other council. Sir Hugh Clifford being the governor-general ushered in the electoral principle which led to the formation of political parties in Nigeria. ${ }^{12}$ Thereafter the first election was held in 1920 on the platform of the Zero-party into the Lagos Council and in 1922, the Clifford Constitution extended the representation of Nigerian in election into the legislative council held in 1923 under the platform of the Nigerian National Democratic Party (NNDP). ${ }^{13}$ This being the first political party in Nigeria, Herbert Macaulay established Nigerian National Democratic Party in 1923 under the elective principles of the Clifford Constitution. The main objectives of political parties at this period were the issue of buying legitimacy for colonial government through limited franchise restricted to Lagos and Calabar municipalities. ${ }^{14}$ The party also served as a platform for local people to express their grievances against the conduct of the colonial elites. ${ }^{15}$ On the other hand, the party was controlled by the educated elites within the party and its activities were restricted to Lagos. ${ }^{16}$ Other political parties

\footnotetext{
${ }^{1}$ J. Oyedepo, Political Parties and Pressure Groups (National open University of Nigeria 2015) 64-65

${ }^{2}$ Ibid

${ }^{3}$ Constitution of the Federal Republic of Nigeria 1999, s229

${ }^{4}$ T. A. Olaiya, Party System, 'Its Peculiarities and Development of Political Practices in Nigeria' (2016)(10)(10) African Journal of Political Science and International Relations 120-125

${ }^{5}$ M. Somer, Introduction to Comparative Politics. $<$ http://home.ku.edu.tr/ musomer/Lecture\%20Notes/INTL204\%20chapter\%209.pdf $>$ accessed 01 May 2018

${ }^{6}$ C. Ewumbue-Monono, 'Independent Candidature and the Electoral Process in Nigeria' (2006) Journal of Africa Election 75

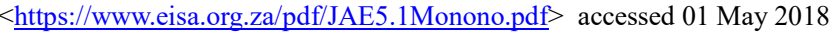

${ }^{7}$ M.C. Lemay, Public Administration (California Wadsworth 2001)

${ }^{8}$ A. Abdullahi, 'Inter and Intra-party Crisis and Sustainable Democratic Rule in Nigeria'(2007)(4)(1) Journal of Social and Policy 35

${ }^{9}$ M. Omilusi, 'An Assessment of Political Parties and Democratic Consolidation in Nigeria's Fourth Republic' (2016) European Journal of Research in Science 34

${ }^{10}$ Omilusi (n2) 37

${ }^{11}$ Ibid

12 Ibid

${ }^{13}$ Ibid

${ }^{14}$ J.S. Omotola, 'Nigeria Parties and Political Ideology' (2009)(1) Journal of Alternative Perspectives in Social Sciences. 616

${ }^{15}$ M. A. Adekeye and A. Abdulrauf, 'Party Primaries, Candidate Selection and Intra-Party Conflict in Nigeria: PDP in Perspective' (2017) International Journal of Politics and Good Governance

${ }^{16}$ Ibid
} 
formed include: People's Union(1923), Union of Young Nigerians(1923), Nigerian Youth Movement(1934) which defeated the Nigerian National Democratic Party (NNDP), the National Council of Nigeria and the Cameroons(1944) ${ }^{1}$, Northern Elements Progressive Association(1945), Northern Elements Progressive Union(1950), Action Group(1951) etc. The Nigerian Youth Movement was the first nationalist movement in Nigeria, it was established to achieve national unity at the expense of ethnic unity and at this time, politics was centered on the actualization of independence. ${ }^{2}$ Action Group was a transformation of the Yoruba socio-cultural organisation known as the Egbe Omo Oduduwa under the leadership of Chief Obafemi Awolowo. ${ }^{3}$ These parties dominated the various regions in Nigeria with the move for independence in the first republic. ${ }^{4}$ Through the Clifford Constitution, which provided the need for the formation of political parties in Nigeria, over fifty political parties have been formed since 1923 till date. In other words, the Clifford Constitution paved way for multi-party system in Nigeria. The first republic (1960-1966) witnessed political participation from three major political parties representing the three regions (Yoruba, Hausa and Igbo) of Nigeria. The political parties were the Action Group (AG), Northern Peoples' Congress (NPC) and the National Council for Nigeria and the Cameroun (NCNC). These political parties participated and contested in the election held on the eve of the independence that ushered in the democratic and parliamentary system of government. ${ }^{5}$ The massive electoral fraud in the 1964 and 1965 election led to a political crisis which led to the collapse of the first republic, civil war and the entry of the military into Nigerian politics. ${ }^{6}$ The military devoted a lot of attention into the formation of a new type of political party that would be national and less divisive. Both Gowon and Muritala regimes tried to steer the country towards a zero party or one party system in order to establish state control over political process. ${ }^{7}$

The second republic (1979-1983) also witnessed the multi-party system, after the thirteen years of military rule. ${ }^{8}$ While new parties (such as Peoples Redemption Party (PRP), Great Nigerian Peoples Party (GNPP) and the Nigerian Advanced Party (NAP etc) were formed, some were also replaced. For instance, the National Party of Nigeria (NPN), the Unity Party of Nigeria (UPN) and the Nigerian Peoples Party (NPP) replaced the Northern Peoples' Congress (NPC), Action Group (AG) and the National Council of Nigeria and the Cameroun NCNC). ${ }^{9}$ By the election held during the transition period, the National Party of Nigeria (NPN) led by Alhaji Shehu Shagari won the election but his administration was accused of fraud, corruption, ruined economy, intra/inter party rivalry and electoral fraud which returned him for second term. As a result of which the military took over in 1983. The formation of political parties in the third republic (1992-1993) was restricted to two political parties as opposed to the multiplicity of political parties in the first and second republic. ${ }^{10}$ Two major Political Parties (Social Democratic Party (SDP) and the National Republican Convention(NRC) were officially formed by the state after many consultations, experiments with different political associations and the dissolution of associations that applied for registration. ${ }^{11}$ However, the country returned to a multi-party system in the fourth republic with the commencement of political activities through Peoples' Democratic Party (PDP), All Peoples' Party (APP), All Nigerian Peoples' Party (ANPP) and the Alliance for Democracy (AD). Apart from these political parties, other political parties were also formed. The fourth republic was inaugurated on the $29^{\text {th }}$ day of May 1999 , it also marked the Nigerian democracy day till date. ${ }^{12}$ Prior to the inauguration of the fourth republic, the military head of state, made provision for the transition from military to civilian rule by the establishment of the Independent National Electoral Commission (INEC) and by allowing political parties to register and participate in the general election held where Chief Olusegun Obasanjo of the Peoples' Democratic Party won the presidential election. Despite the fact that a lot of political parties were registered, only three political parties were qualified to participate in the election. ${ }^{13}$ The political parties are the Peoples' Democratic Party (PDP), All Nigerian Peoples' Party (ANPP) and the Alliance for Democracy (AD). After the first general election, other political parties registered also met the criteria for participation as provided by the Independent National Electoral Commission (INEC), thereby paving way for multi party system in Nigeria.

\footnotetext{
${ }^{1}$ Formed by the Igbo federation in Lagos by Nnmadi Azikwe

${ }^{2}$ G. M. Brown, Nigerian Political System: An Analysis (2013)(3) International of Humanities and Social Science. 174- 176; Some of the members of the movement were Nnamdi Azikwe, Obafemi Awolowo, Ernest Ikolo, K.A. Abayomi and Samuel Adesanya.

${ }^{3}$ Omotola (n18)

${ }^{4}$ R. L. Sklar, R.L, Nigerian Political Parties: Power in an Emergent African Nation,(Princeton University Press, 1963)

${ }^{5}$ Brown (n22)

${ }^{6}$ J. Liebowitz and J. Ibrahim, A Capacity Assessment of Nigerian Political Parties: Democratic Governance for Development (DGD) Programme, 2013. <www.ng.undp.org/content/dam/nigeria/.../dgd assessment of political parties.pdf $>$ Accessed 23 May 2018

${ }^{7}$ Ibid 13

${ }^{8}$ The 1979 Constitution was enacted during the transition period of the military to civilian rule

${ }^{9}$ Omotola (n23)

${ }^{10}$ Brown (n25)

${ }^{11}$ E. E Osaghae, , Crippled Giant: Nigeria Since Independence, (Hurst and Company 1998)

${ }^{12}$ However, recently June 12 has been declared as the democracy day by President Mohammadu Buhari commencing from 2019.

${ }^{13}$ A. P. Adebisi, 'The Rise and Decline of Political Parties in the Fourth Republic in Nigeria: Implications for the Consolidation of Democracy’ (2015) Afro Asian Journal of Social Science 5-7
} 


\section{Multi party system in Nigeria}

Multi-party system suggests a number of political parties different from each other but with the same goal and equal opportunity of contesting for elective positions. Multi-party system is a system where there are more than three political parties having equal rights to participate in an election. It is one of the features of a federal state. It usually exists where multiple social issues and proportional representation are indispensible within the system and it promotes political awareness and competition. ${ }^{1}$ Multi-party system allows the opposition parties to criticize and scrutinize the incumbent government and strive to work harder in order to prove their competence in the eye of the electorates. It creates opportunity for freedom of association and promotes the liberty of the people as provided in the Constitution. ${ }^{2}$ It allays the fear of marginalization and domination within the political system. ${ }^{3}$ In a multiparty system, each party represents a distinct role and principle, which the political party represents. In a democratic setting, it gives the people or the electorate the opportunity to choose from a number of political parties, thereby preventing autocracy and dictatorship from any of the political parties. However, multi-party system could arise out of Intra party and inter party conflict, leading to decamping/defecting, formation of new political parties, and ethnicity. The ethnic diversity of Nigeria has contributed a great deal to the multi party system in Nigeria. The multi-party system stretches along a continuum ranging from two-party system to one of a numerous political parties. For instance, in the United States, there have always been quite a number of political parties but only two political parties are represented in the country's congress the Democratic Party and the Republican Party. Also in the case of Britain, which operates a multi-party system with its long history of multi-party democracy, at the end of the May 2015 election, eleven political parties won representation in the House of Commons, with the conservative Party under David Cameron forming the government with 331 seats, followed by Labour (232 seats). Another country that operates a multi-party system is India. In the 2014 election in India, there were 1703 registered political parties but only six were recognised as national political parties. ${ }^{4}$ The British parliament recognises the opposition parties, this opposition officially reflects in the demarcation between the government and the opposition. For instance, the government and the opposition sit opposite each other in the parliamentary chamber. Also in Ghana, multi-party system was fully recognised in 1992, by virtue of the Ghanaian Constitution 1999. Despite the recognition of multi-party system and the participation of multiplicity of political parties, only two political parties (New Patriotic Party and National Democratic Congress) were recognised in the fourth republic. $^{5}$

In Nigeria, one tribe or ethnic group dominates most of the political parties and their leadership positions. ${ }^{6}$ For instance, majority of the leaders and members of Alliance for Democracy (AD) leaders were Westerner and the All Nigerian Peoples' Party (ANPP) was dominated by the Northerner until recently where intra party conflict led to coalition and defection leading to mixture of members from different tribes and regions. ${ }^{7}$ Also, the financial support political parties received from the state by virtue of the provision of the electoral Act has contributed to the multiplicity of political parties in Nigeria. Some political parties were formed for the purpose of receiving the financial benefit only to fizzle out after the election. ${ }^{8}$ On the other hand, it often leads to the formation of coalition government/movement (e.g. Coalition for Nigerian Movement formed by Chief Olusegun Obasanjo the former President of Nigeria), lack of trust, assassination mismanagement of fund and other challenges affecting the political system in Nigeria.

\section{Challenges of multi party system in Nigeria}

Multi party system in Nigeria is prone to many challenges ranging from intra party and inter party conflict, which often affect the nation's democracy. Most intra party conflict often leads to fractionalization, division within the party and decamping or defection from one political party to another. There is weak internal party loyalty and the aim of members joining a political party lies with the party that offers opportunity and chance of contesting for an elective position. ${ }^{9}$ Intra party conflicts often arise as a result of the greed or struggle for political power which

\footnotetext{
${ }^{1}$ Olaiya (n8)

${ }^{2}$ Constitution of the Federal Republic of Nigeria 1999 s40 \& s35

${ }^{3}$ K. C Nwajoku, Political Parties and Democratic Governance in Africa : A Case Study of Nigeria, 1960 till date. $<$ http://www.pekeafr.org/doc/rennes2005/nwajokurennnove05.pdf $>$ accessed 01 May 2018

${ }^{4}$ B. Naanen, 2015 Election: Threatened Collapse of Opposition and the Future of Democracy in Nigeria $(2015)<\underline{w w} . i n e c n i g e r i a . o r g>$ accessed 01 May 2018

${ }^{5}$ A. P. Wogu, M.A Sholarin, F.E. Olu-Owolabi, O. Adegbuyi, B.E Agoha and A. Elegwele, 'Political Bahaviour and Party Politics in a Democracy : A Comparative Analysis of Ghana \& Nigeria’ (2015)(22)(3) Wulfenia Journal 556

${ }^{6}$ Naanen (n37)

${ }^{7}$ For instance the member of Action Congress of Nigeria, All Nigeria Peoples' Party and Congress for Progressive Change formed an alliance known as the All Progressive Congress (APC) this alliance was formed against the Peoples' Democratic Party being the ruling party(1999-2015) before the All Progressive Congress (APC) took over power in 2015

${ }^{8}$ Adebisi (33)

${ }^{9}$ P. Domingo and C. Nwankwo, Review of International Assistance to Political Party and Party System Development. Case study Report:

Nigeria (Oversea Development Institute 2010)
} 
creates access to the accumulation of wealth of the nation. ${ }^{1}$ The major challenges facing the multi-party system in Nigeria are:

a. Favouritism: this is a challenge often caused by intra party conflict where an influential/rich candidate is placed far and above a more competent candidate. This is often the norm in most political parties of Nigeria where only those in the good book of the party leaders are allowed to contest in an election while the unfavourable party is asked to step down for their candidate. Another agent of favouritism is the kinsmen principle where selection of party representatives are based on kinship, tribal and religious factors.

b. Paucity of political ideology: Political ideology refers to the promises or the activities to be carried out by the political party when its candidate is voted into office and it controls the actions of the political party. ${ }^{2}$ According to Ayeni-Akeke, an action-oriented system of ideas or belief that identifies the problems besetting the structures process of a society and the alternative programs and strategies for establishing another system that will overcome the observed deficiencies is a political ideology. ${ }^{3}$ It is a set of dynamic ideas about politics, which are related to one another. ${ }^{4}$ This ideology is contained in the party's manifesto prior to the conduct of the election and often made available to the electorates. Most of these ideologies are the same, watery, without sense of direction and do not meet the needs of the people and few ideologies that are accepted by the people do not see the light of the day after the political party has been voted into power. Rather than putting the welfare and interest of the people at the peak of its affairs, political parties are more interested in accumulation of public fund. One of the reasons for party defection or decamping or cross carpeting is the lack of viable political party ideology, which often discourages members from maintaining or staying within their political party and also caused a lot of political party to fail.

c. Absence of internal democracy: According to Salih, internal democracy is the support for the general interest of the party members, public and the state. ${ }^{5}$ It is a democratic process, which involves accountability and transparency in all party affairs like selection of party leaders, flag bearer and other officials of the political party. ${ }^{6}$ It means running the affairs of the party appropriately and in accordance with the laid down rules governing the party. Most political parties in Nigeria do not carry their members along in decision-making, selection of candidates for elective positions and the general administration of the party. Party marginalization, lack of change of leadership and poor communication often erodes the existence of internal democracy. Although Internal democracy represents the interest of all members of the party and maintains unity among members, ${ }^{7}$ it is often not practice in most political parties in Nigeria and it often leads to cross-carpeting or defection of party members. The non-inclusive system of participation, decision-making, lack of opportunities for broad input, weak mechanisms for redressing grievances and denial of rights that exist within Nigerian political parties are as result of lack of internal democracy. ${ }^{8}$

d. God-fatherism: God-fatherism exists where political kingmakers and gladiators manipulate the political system to enthrone their crowned political stewards. ${ }^{9}$ God-fatherism is a corrupt practice that happens within the political party when political office holders owe their positions to the efforts of the godfather. ${ }^{10}$ According to Gambo, Godfatherism is the practice of political office seekers getting connected to an individual who is believed to have the ability to deliver the desired outcome in an election. ${ }^{11}$ It is not philanthropy but it is marked by deceitful and undemocratic acts such as violence, bribery and corruption for the sake of perpetrating the wishes of the Godfather. ${ }^{12}$ It promotes electoral violence and malpractice. ${ }^{13}$ Godfathers are individuals whose power does not twig only from wealth but from their

${ }^{1}$ A. J. Momodu and M. G. Ika, 'The Implications of Intra-Party Conflict on Nigeria's Democratization'(2013)(13)(6) Global Journal of Human Social Science and Political Science

${ }^{2}$ Ibid

${ }^{3}$ A. Ayeni-Akeke, Foundation of Political Science (Ibadan:Ababa Press Ltd 2008)168

${ }^{4}$ J.S. Omotola, 'Nigeria Parties and Political Ideology' (2009)(1) Journal of Alternative Perspectives in Social Sciences. 616

${ }^{5}$ S.M. A. Mohamed, The Challenges of Internal Party Democracy in Africa in UNDP. A Hand Book on Working with Political Parties (New York UNDP, 2006) 54-55.

${ }^{6}$ E.M. Etim and M. A. Kwasau, General Election and the challenges of Sustainable Democracy in Nigeria: A Study of 2015 Governorship Election in Kaduna State. (2015) < http://www.unimaid.edu.ng/oer/Journals-oer/Social/General/Paper\%20D\%207.pdf > accessed 01 May 2018 ${ }^{7}$ Momodu (n42)

${ }^{8}$ A. Ikelegbe, Political Parties and Violence (National Conference on Political Parties and Future Democracy in Nigeria, organized by National Institute for Policy and Strategic Studies (NIPSS), Kuru in Collaboration with the Democracy and Governance Development Project (DGD) II of UNDP June 2013); Etim and Kwasau (n47)

${ }^{9}$ M. A. Kwasau, 'The Challenges Democratic Consolidation in Nigeria's Fourth Republic' (2013) European Scientific Journal 186

10 Ibid

${ }^{11}$ A.N. Gambo, 'Godfatherism and Electoral Politics in Nigeria' in Money, Politics and Corruption in Nigeria. (IFES Publications 2006) 8890

${ }^{12}$ Etim and Kwasau (n48)

${ }^{13}$ Omilusi (n14) 40 
ability to deploy violence and corruption to manipulate political systems in support of the politicians they sponsor. ${ }^{1}$ According to Albert, Godfathers are political gatekeepers who use their influence to block the participation of others in Nigerian politics, and they dictate political participation and conditions. ${ }^{2}$ Godfathers control the policies, resources, strategies in the state and they rule by proxy. ${ }^{3}$ Godfathers pay media men to report their activities; they grant regular interviews for publicity/popularity, they also pay followers to place congratulatory messages about them in the media for the enhancement of their public image. ${ }^{4}$ In the realm of the godfatherism, the godfather assures the godson of electoral success while the godson uses his power to advance political, economic, and social influence of the godfather after winning the election. ${ }^{5}$ The activities of the godfathers block and frustrate the values of democracy in the state thereby hindering a qualified candidate from taking up such elective position. ${ }^{6}$ It promotes corruption and mediocrity and the incumbent godson tries to satisfy and meet the needs of the Godfather at the detriment of other competing demands on the available limited resources. ${ }^{7}$ It typically plays electoral politics with no respect for the Constitution of the parties and the democratic process. ${ }^{8}$

e. Cross carpeting: cross carpeting or defection or decamping means moving from one political party to another. Party members leave their political party for another due to internal crisis or conflict within the party, lack of political ideology, lack of internal democracy and crave for power. A factor threatens the democratic process of a nation. Cross carpeting affects the progress of the political party, the sustainability of democracy and it poses a threat to the multi-party system. ${ }^{9}$ Nigerian politics is in constant demonstration of a high rate of political prostitution. For instance, despite the provision of section $109^{10}$ of the Constitution of the Federal Republic of Nigeria, 1999 on the effect of defection or cross carpeting by elected legislative officials, there have been series of defection in constant violation of this provision of the Constitution without any form of report or prosecution of the culprits by the affected political parties. ${ }^{11}$ Defection is also easy in Nigeria because of the poor political ideology of the political parties where nothing is lost by the party officials cross carpeting or moving to another political party. ${ }^{12}$ According to Mbah, cross carpeting has being before Nigeria's independence and is older than her sovereignty, it has been shaped and sharpened by colonialism and sustained by structures of post-colonial state. ${ }^{13}$ According to Aleyomi, the two major reasons for cross carpeting in a multi- party system are the move from rival political parties into the ruling party with the ambition of contesting in election and also participating in the parties primaries. The second reason is an undulate effect of the first reason in the sense that when they do not win in the party defected to, they move back to their former party or form a new political party with an excuse of leaving the party. ${ }^{14}$

\section{Necessity of independent candidature in Nigeria}

Independent candidature is an alternative platform where citizens have the right to exercise their constitutional right in an election process. Independent candidate is a person who runs or contest for an election without belonging to any political party. An independent candidate is not affiliated or attached to any political party. He is not bound by any political party when voted into office and it is the manifestation of dissatisfaction with partisan politics. Unlike Nigeria, independent candidates are allowed to contest in an election. According to Brancati, independent candidates are individuals who compete for political office but do not belong to any political party. ${ }^{15}$ Makulilo defines Independent candidate as an individual who contests an election without political party support

\footnotetext{
${ }^{1}$ Ibid 39; Human Right Watch, Criminal Politics: Violence, "Godfathers" and Corruption in Nigeria (2007)(19) Human Right Watch 33

2 I. O. Albert, Explaining 'Godfatherism' in Nigerian Politics, (2005)(9) African Sociological Review, 81

${ }^{3}$ Kwasau (n51)

${ }^{4}$ Omilusi (n55)

${ }^{5}$ Ibid

${ }^{6}$ Kwasau (58)

${ }^{7}$ Albert (n57) 81

${ }^{8}$ T. Abu, 'Credible Election in Nigeria' Daily Trust Newspaper ( Nigeria 2014) <www.dailytrust.com.ng $>$ accessed $01 \mathrm{May} 2018$

${ }^{9}$ M. B. Aleyomi, 'Election and Politics of Party Defection in Nigeria : A Clue from Kogi State'(2013)Covenant University Journal of Politics and International Affair. 11

10 "A member of a House of Assembly shall vacate his seat in the house if - being a person a person whose election to the House of Assembly was sponsored by a political party, he becomes a member of another political party before the expiration of the period for which that house was elected"

${ }^{11}$ Naanen (39) 7

${ }^{12}$ Ibid

${ }^{13}$ P. Mbah, Party Defection and Democratic Consolidation in Nigeria, 1999-2009 (2011) Afro Asian Journal of Social Sciences 2

${ }^{14}$ Aleyomi, (n64) 117; C. Gbolahan and M. Duruji, Multi-party System in Nigeria's Fourth Republic : Challenges and Suggestion. (2017) Covenant University Conference on E-Governance in Nigeria. 448

${ }^{15}$ D. Brancati, 'Winning Alone: The Electoral Fate of Independent Candidates Worldwide' (2008)(70)(3) Journal of

Politics, 648-662.; L. Weeks, 'We Don't Like (to) Party: A Typology of Independents in Irish Political Life, 1922-2007,' (2009)(24)(1) Irish

Political Studies 24(1): 1-27
} 
structures. ${ }^{1}$ The need for independent candidate stems from the disappointment and malpractices of the various political parties which has affected the electorates, growth and development of the nation greatly. It is one of the major political rights that should be enjoyed under a democratic setting and no one should be compelled to join a political party before he can contest in an election. For instance with particular reference to the $145^{\text {th }}$ session in Paris, the Declaration on the Criteria for Free and Fair Elections (which makes provision for independent candidate) was adopted by the inter-parliamentary council. The declaration provides that everyone has the right to take part in the government of their country and shall have an equal opportunity to become a candidate for election, either as an independent candidate or through an organisation for the purpose of competing in an election. ${ }^{2}$ Also by virtue of the Provisions of the United Nations International Covenant on Civil and Political Rights (CCPR), independent candidate is also recognised as the political right of a citizen. It provides that, every citizen shall have the right and opportunity and without unreasonable restriction, to take part in the conduct of public affairs, directly or through freely chosen representatives, to vote and be elected at genuine periodic elections which shall be by universal and equal suffrage and shall be held by secret ballot, guaranteeing the freedom of expression of the will of the electors. ${ }^{3}$ In other words, political party should not be the only platform for people to contest in an election provided there are no restrictions or any disqualifications, which would prevent such candidate from contesting. ${ }^{4}$

Due to the fear of domination of independent candidate over the political parties in Tanzania, the government has kicked against an individual contesting for an election without belonging to any registered political parties. This notion was however instigated in 1960 where an active member of the prominent political party called Tanganyika African National Union (TANU), Herman E. Sarwatt, left his political party (TANU) and contested for the post of members of the National Assembly as an independent candidate in the Mbulu Constituency. ${ }^{5}$ On the other hand, some members of TANU party in Mbulu demanded for another candidate because the candidate contesting against Sarwatt was not popular but the TANU party leaders rejected their request. ${ }^{6}$ When the election was conducted, Sarwatt won the election as an independent candidate against the candidate of the TANU party, which made members and leaders of TANU party unhappy. ${ }^{7}$ As a result, of the case of Sartwatt, independent candidature became unacceptable and unrecognized by the government of Tanzania.

Although independent candidature is currently not in practice in Nigeria but it can be historically traced to the period between 1954 and 1959 when more than 300 politicians ran as independents $\backslash$ candidates in the various regional elections and the 1959 federal election. ${ }^{8}$ In 1956, independent candidates from the western region contested for the legislative seats, in 1957, independent candidates together with candidates from other political parties contested for the Eastern legislative seats ${ }^{9}$ while in 1959 election, 820 party-sponsored candidates and 133 independent candidates, nine of whom were elected into Parliament. For instance, in 1955 Abraham Adesanya, a fresh law graduate and a native of Ijebu-igbo, declared his ambition as a member of the defunct Action Group (AG) led by the late Chief Obafemi Awolowo. ${ }^{10} \mathrm{He}$ sought the House of Assembly ticket to represent Ijebu-igbo constituency but the party elders told him to hold on till 1959, which he refused. ${ }^{11}$ As a result of this, he left the party (Action Group) and contested as an independent candidate. Independent candidature was also experienced in the old Ondo Province where Akinola Aguda ran as an independent candidate to represent the Western Region House of Assembly constituency against the Action Congress and the National Council of Nigerian Citizens' candidate. ${ }^{12}$ In 1960, Alvan Ikoku was defeated by his son Samuel Goomsu Ikoko who contested as an independent candidate into the South-eastern House of Assembly. ${ }^{13}$ Samuel Odulana from Ibadan, contested for the House of Representatives as an independent candidate, he won the election as opposed to Adesanya and Aguda who lost in the respective constituencies. ${ }^{14}$ Also in Russia, independent candidature is recognised, in practice and a major political force.

Between the periods of 1993-2003, independent candidates won majority of the legislative seats in Russia, in other words the electorates gave more recognition to independent candidate as opposed to the activities of the

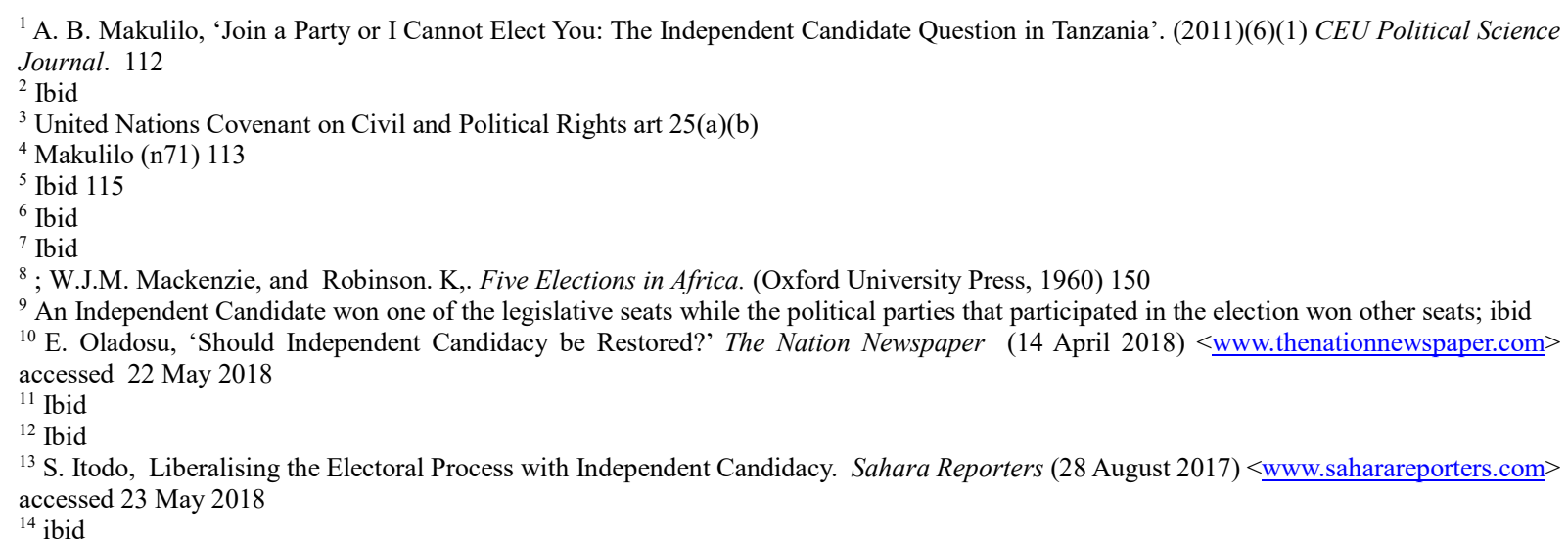


political parties. In Algeria, six independent candidates and one candidate from a political party contested in the April 1999 election. ${ }^{1}$ In the 2005 election conducted in Zimbabwe, about 17 independent candidates stood against 253 candidates of political parties. ${ }^{2}$ Independent candidature dates back to 1910 in Australia where candidates were given the opportunity to use the party logo or label at the time of the election with the promise to follow the decision of the party if elected into office. ${ }^{3}$ Despite the fact that independent candidature is practiced in Australia, there are multiple political parties in operation. The reason for the rise in political parties can be traced to the protest for limited policy choice offered by the large parties and the dislike for the domination of party elites and the political process. ${ }^{4}$ With the development of independent candidature in Australia, about 25 independent candidates were elected at the May 2002 general election to the lower house of state and commonwealth parliament. ${ }^{5}$ Between 1993 and 2002, 44 independent candidates were elected into the state and common wealth lower house. Independent candidates were voted for due to their popularity within their community as opposed to party affiliation. ${ }^{6}$

Apart from the two major political parties (Labour and Liberal) in Australia, there are other minor political parties (Australian Democrats, Green, One Nation Party etc) formed based on social and economic change. Other candidates who fell out of their political parties due to disagreement also formed their own parties known as the independent parties (e.g independent Liberal). These independent parties fall into the category of political parties and independent candidates. According to Sharman, independent candidates lived or died by the support of a narrowly defined community. He stated further that all state and commonwealth lower houses except Tasmania use single member districts to elect their members, which means that independent candidates are a direct challenge to the ability of the big parties to secure majorities where they count most in the lower house of parliament where governments are formed. ${ }^{7}$ While minor parties are frustrating, independent parties are more serious and direct threat to the targets of the major political parties. ${ }^{8}$ In 2014 and 2015, John Madigan, Jacqui Lambie and Glenn Lazarus were elected as independent candidates into the Australian legislative seats. ${ }^{9}$ On the other hand, while independent candidates are major threat to political parties in Australia, the ruling party is the major threat to other political parties in Nigeria. Nigeria being a multi-party state is confronted with a lot of inter party conflict and domination. In the United States, George Washington the former president of United States was elected as an independent candidate while Bernie Sanders was elected into the United States Congress as an independent candidate in $2007 .{ }^{10}$ Other countries where independent candidate is actively in practice are Georgia, Portugal Philippines, Sudan, etc. These are instances where independent candidature is in practice and has strived successfully in the countries' democratic process.

It is pertinent to state that independent candidature is a democratic global phenomenon, which some countries have embraced while others have rejected it out rightly. Independent candidature is a practice that is well established in emerging democracy and a feature of the democratic process. Although independent candidature has recorded a lot of successes in these countries, one of the reasons for its outright rejection is to the effect that it would jeopardize the interest of the people and the electoral system, it would trigger the trend of ethnicity and personal politics. ${ }^{11}$ Just like Nigeria, independent candidature is not recognised in Tanzania and some other countries. Despite the multiplicity of political parties in Nigeria, the economic, cultural, social and political condition of the nation has not improved. The new political parties that are established are not different from the old political parties. These political parties have not convinced the electorates in terms of their administration, ideology, and internal democracy and their readiness to perform better than other political parties that have been in power. The need for independent candidature arises from the various challenges associated with the multi-party system and the need for Nigerian citizens to exercise their political right as citizens of the country. It will address the socio-economic challenges, which political parties cannot resolve, and it will bring intra/inter party conflict to the barest minimum. With independent candidature in place, popular politicians who are perceived as victims of mutually destructive scheme by electorates will be rehabilitated, the electorates who are disappointed in the activities of political parties would have the opportunity of voting for the independent candidate of their choice. ${ }^{12}$ Independent candidature if allowed in Nigeria would eradicate the idea of do or die affair in Nigerian politics,

\footnotetext{
${ }^{1}$ Ewumbue-Monono (n10) 88

${ }^{2}$ Ibid 84

${ }^{3}$ C. Sharman, Politics at the Margin: Independences and the Australian Political System. (Paper Presented at the Department of the Senate Occassional lecture Series at the Parliament House) $<$ https://www.aph.gov.au/binaries/senate/pubs/pops/pop39/sharman.pdf $>$ accessed 01 may 2018

${ }^{4}$ Ibid

${ }^{5}$ Ibid

${ }^{6}$ Ibid

${ }^{7}$ Ibid

${ }^{8}$ Ibid

${ }^{9}$ Oladosu (80)

${ }^{10}$ Ibid

${ }^{11}$ Makulilo, (n74)

${ }^{12}$ Ewumbue-Monono (n85) 89
} 
imposition of candidates on the electorates and the exclusion of candidates by party elders/godfathers from contesting in an election.

\section{Effort of the legislature towards independent candidature in Nigeria}

Independent candidature was raised as a major issue at the outcome of the 2005 National Political Reform Conference set up by Chief Olusegun Obasanjo, former President of Nigeria, it was raised in the draft bill on electoral reform by late President Umaru Y'Adua, and it was raised during the National conference held in 2014 during President Goodluck Jonathan administration. ${ }^{1}$ It was also raised during the All Progressive Congress (APC) on true federalism held in January 2018 The Constitutional and Electoral Reform committee led by Senator Ken Nnamani recommended independent candidature for Nigeria. According to the committee, independent candidature will go a long way in addressing the bureaucratic process involved in politics. Prior to the constitution of this committee, Senator Stella Oduah championed the inclusion of independent candidature in the Nigerian Constitution at the beginning of the $8^{\text {th }}$ Assembly. According to her, independent candidature would end the impunity of imposition by political party and ensure the right candidates are elected either through political parties or through independent candidates. She stated further that it will give the electorates the opportunity to choose freely whom to represent them rather than the political party. ${ }^{2}$ When the motion for amendment of the Constitution and the Electoral Act was moved at the upper legislative house, eighty-two members voted in favour of the motion while only five members voted against the motion. ${ }^{3}$ Although, the All Progressive Congress (APC) committee on true federalism recommended independent candidature during the party's congress on true federalism, it has not been implemented. The committee however recommended the inclusion of independent candidature in the Constitution and the Electoral Act. The sections to be amended to make provision for independent candidature in the Constitution are Section 65(2), 106(d), 131(c), 142(1), 176(c) and of the Constitution. The amendment provided for independent candidature in local government election, it prescribes condition for operating independent candidature at the local government level by introducing constituency based nomination process. In the case of the Chairman and House of Assembly aspirants, fifty (50) registered voters from each ward of the electoral wards in the respective local government area will be required to validate an independent candidate. Councilors will require the signatures of twenty (20) registered voters from each of the polling unit in the respective electoral wards. ${ }^{4}$

However, the national assembly has also included independent candidature in the bill for Constitutional amendment. The provisions of the bill relating to the constitutional amendment as it relates to independent candidature are as follows:

Section $65,106(d), 131(c), 177(2)$ of the Constitution was altered by inserting a new subsection as followsA person shall be qualified for election under subsection (1) of this section as an independent candidate if-

a) He is not a member of any registered political party and has not been so registered by any political party at least six(6) months prior to the date set for the elections at which he intends to contest;

b) He is nominated to contest the elections by persons who must not be registered members of any political party at least six(6) months prior to the elections;

c) He is not disqualified for election by any provisions of the Constitution; and

d) He has fulfilled other requirements for election set forth by an Act of the National Assembly including the payment of nomination fees".

In addition to section 65, for election into the Senate or House of Representatives, independent candidates shall be nominated by at least 10 registered voters each of whose signature on the nomination form shall be verified and authenticated as provided by law, from at least two-thirds of the electoral wards in the relevant electoral constituency and subject to a deposit payment as may be prescribed by an Act of the National Assembly which shall prescribe the conditions for refund of such deposit.

Section 142, 187 of the Constitution was altered by inserting a new subsection (3) as follows:

"in any election to which the provisions of subsection (1) of this section relate, a candidate standing for election to the office of the president/governor as an independent candidate shall not be deemed to be validly nominated unless he nominates another candidate as his associate running for the office of vice president/deputy governor, who shall not be a member of any registered political party and has not been so registered by any political party at least six (6) months prior to the date set for the

\footnotetext{
${ }^{1}$ Editorial, 'A vote for Independent Candidacy' Daily Independent ( 11 May 2017)

2 S. Oduah, 'Independent Candidacy will Remove Party Impunity' The Guardian (07 August 2017)

${ }^{3}$ F. Nwabufo,' Senate Approves Independent Candidacy, restricts tenures of Governors, President'. The Cable (26 July 2017) https://www.thecable.ng/breaking-senate-approves-independent-candidature accessed 22 May 2018

${ }^{4}$ Itodo (82)
} 
elections at which he intends to contest and the candidate shall be deemed to have been elected to the office of vice president/deputy governor if the candidate who nominated him is elected to the office of president/governor."

Also in respect of the provision of independent candidate in the Electoral Act 2010, the legislative house drafted a bill to be passed into law to include independent candidature. Section 87 of the Electoral Act to be amended by inserting a new subsection 12 as follows-'Nothing in this section shall prevent any person from contesting any elective position as an independent candidate subject to the fulfillment of any conditions as may be stipulated by Constitution and any other law'

Although these bills have not been passed into law, it is a welcome development to the recognition and acceptance of independent candidature into the democratic process in Nigeria. However, in order to prevent the abuse of this democratic process, the conditions for the eligibility of independent candidate should be stringent. These stringent conditions or criteria would prevent the process from being abused and it will also prevent candidate who merely wish to contest for the purpose of gaining popularity from achieving their aim.

\section{Concluding remark and recommendation}

Political parties are the major players in Nigerian politics. They have equal right to contest for elective positions and to participate in an election. With the multiplicity of political parties in Nigeria, there are avalanche of challenges bedeviling these political parties (unhealthy rivalry, assassination, insecurity, violence etc) which have necessitated the need for independent candidacy. These challenges stem from the lack of internal democracy, undemocratic process of selecting candidates, imposition of candidates, godfatherism unhealthy rivalry, unhealthy competition etc. Independent candidature is not new to Nigerian politics and democratic process. Independent candidature is well established in emerging democracy and it is a feature of democratic process. Its origin can be traced to the multiplicity of Political Parties and the need to contest for an elective position which is not available within the political party and which aspirants were not given the opportunity to contest for within the party. As opposed to multi-party system, independent candidature would allow trusted individual to contest in an election without any form of political participation, it will create a healthy competition between political parties and the independent candidates, and it will reduce unfair selection process within the political parties. Despite the fact that some of the independent candidate lost the election, majority of these independent candidates left their political parties due to intra party conflict and power struggle. The following recommendations are made: independent candidature should be enacted into law in Nigeria and where it is enacted into law, it should be subjected to strict conditions to avoid being abused and to eradicate attention seeking politicians who might want to use independent candidature to seek popularity. Independent should be allowed to operate along side with other political parties without any form of discrimination or disenfranchisement. There should be public enlightenment and awareness on what the populace stands to gain if independent candidature is enacted into law in Nigeria and its importance to the democratic process of the country. The remuneration of political office holders should be reduce so that politician would see political position as the service to the people rather than as a place for accumulation of wealth and a contest of life and death. 